\title{
Political Participation And Electoral Society
}

\author{
Nina Yuslaini \\ Islamic University Lecturer Fisipol Riau \\ Riau, Indonesia \\ E-Mail: Ninayuslaini@Soc.Uir.Ac.Id
}

\author{
Pahmi Amri \\ Universitas Islam Riau \\ Pekanbaru-Indonesia \\ Fahmi.amri39@gmail.com \\ Made Devi Wedayanti \\ Univeritas Islam Riau \\ Pekanbaru-Inonesia
}

\begin{abstract}
_public political participation in local elections and deputy head of the region are directly regulated in Law no. 32 of 2004. Community participation object of study which is interesting considering the condition of the people are getting smarter and active. Most democracies, elections are considered the emblem, as well as benchmarks of democracy itself. Elections held in a filing with the freedom of speech and association. Despite this general election has not become benchmarks also need to be equipped with the measurement of other activities that are more sustainable for example, participation in party activities, lobbying and more. But the dynamics that develop throughout the course of the reform and the implementation of regional autonomy naturally become the main capital community participation in development, with a high level of participation that will further facilitate the development and flow of various aspect Seeing history of elections in Indonesia starting in 1955-2014 decreased level of community participation. Given Indonesia's treading the democratization process, the trend of declining voter participation.
\end{abstract}

Keywords: Political Participation, Democracy, Elections.

\section{INTRODUCTION}

The political participation of the community itself is a form of actualization of the democratic process. It has become very important for the people in the process of political development for developing countries such as Indonesia. As explained in participation, democracy or not a country is seen from how the elections in that country, if participation mayarakatnya is good then the country can be said to be democratic, in this case Indonesia implement a democratic system it is clearly visible to the held first elections in 1955 but the journey even more the level of participation from the public on the wane, it looks increasingly high number of percentage vote.

There are a number of explanations put forward by observers or election organizers about the causes of the nonvoters, including the first administrative problem. A voter does not choose because it collided with an administrative procedure such as a voter card is not listed in the voters' list and so on. The second technical problem that someone decided is not allowed to vote because there was no time to choose, such as having to work on the day of elections, was there a need, be out of town when the election and sebaginya. Third, the lack of involvement of interest in politics (political moment) that one does not choose because it is not related to politics, indifferent and did not look at the elections or local elections as important. Fourth rational calculation that voters decide to opt for consciously do decide to tdak choose, legislative elections seen as pointless, would not bring significant changes, even could be because there is no preferred candidate. [1]

Election (Election) is the means of implementation of the sovereignty of the people in the Republic of Indonesia based on Pancasila and the Constitution of the Republic of Indonesia in 1945 [2]. Besides the election can also be interpreted as the process of election of people to fill political positions. The political office is diverse, ranging from presidents, representatives at various levels of government, the village head. Election itself is a variety of problems on many non-voters has become a concern in every election KPU, KPU actually been trying in various ways to increasing levels of community participation and abstention figure could be as minimum as possible.

\section{DISCUSSION}

In modern political analysis of political participation is an important issue, and lately a lot to learn, especially in relation to developing countries. In the first study of political participation focusing on political parties as the main actors, but with the development of many emerging democratic societies that also want to influence the process of decision-making on public policy. These groups were born in the post-industrial (post-industrial) and the so-called new social movements (new social moment). These groups were disappointed with the performance of political parties and tends to focus on one specific problem (single issue) only with the hope of more effectively influence the decision-making process through direct action. [3]

Build on our unrivaled growing participation of autonomous means to be born of itself, is still limited. Symptoms related to it, if it happens in developed countries is often regarded as a sign of their satisfaction with the management of political life. But this is happening in developing countries is not always the case. In some countries people are apathetic, the government is the government faced was how to increase participation, because if participation deadlocked, can be two things that cause "anomie" and "revolution". 
Another problem in some countries that the construction process runs smoothly. There expanding urbanization and education network and increasing mass communication has driven many groups that occur apathetic to be active in the political process, through the activities of various organizations such as trade unions, farmers' organizations, women's organizations, youth organizations, political parties, and so on. Samuel P. Huntington argued that the rapid development, and participated many new groups in politics in a short time, can be destabilizing. [4]

Still relatively low public participation in the process of making the implementation of public policies in Indonesia, is proof of how institutional design alone is not enough. A set of institutions, such as the existence of laws that guarantee freedom of opinion, expression and association, as well as an opportunity for the representatives and represented to interact (engagement), does not necessarily encourage the public's participation. [5]

To clarify the concept of participation means there are several formulas for understanding political participation, elections and democracy as follows:

Participation politics is basically Badian of political culture, due to the existence of political structures in society, such as political parties, interest groups, pressure groups and mass media also critical and active. This is an indicator of people's involvement in the life politk (participation). While the notion of political participation itself is an activity of a person or group of people to participate actively in political life, among other things by choosing the country's leaders and directly or indirectly, influence government policy (Public Policy). These activities include actions such as voting in elections, attend meetings, make contact (contacting) or lobbying with government officials or parliamentarians, being one of the party members with direct social movements ation and so on. [6]

In addition, participation can be interpreted as slaah an important aspect of democracy. Participation is the extent of public participation in political activities whether they are active or passive, direct or indirectly to influence government policy. Kumorotomo Wahyudi said participation is various shades of mass and individual actions that demonstrate the reciprocal relationship between government and citizens [7]

Forms of political participation can be seen from the form of a political participation do. Forms of political participation be viewed in terms of activities are divided into two, namely

\section{a. Active Participation}

is a form of participation-oriented in terms of inputs and outputs of a political system. For example, the activities of citizens submitted a proposal on a common policy, filed a public policy alternatives that are different from government policy, criticism and suggestions for improvements to straighten discretion, pay taxes, and participate in the activities of government leadership election.

\section{b. Passive Participation}

is a form of participation is oriented to the terms of the output of a system poliitik. For example, the activities obey the rules / orders, receiving, and carry away any government decision. [8]

The best way to overcome crisis and participation is an incremental increase gradually as practiced by the British in the 19th century. In this way would provide the opportunity and time to the institution and the people to adjust diri.seorang Michael Roskin observer stated that South Africa is an example of a country that quickly realized the importance of political participation. Countries previously ruled by the white minority is quickly opened up opportunities for the roles of the people. [9]

Democracy adopted in Indonesia, namely democracy based on Pancasila, can still level of development and on the nature and characteristics there are various interpretations and views. But that can not be denied is that some of the fundamental values of constitutional democracy quite clearly implied in our Constitution to explicitly mention that animates the two principles. [10]

\section{CONCLUSION}

One form of implementation of the value of democracy is citizen participation in electoral politics, as for other forms of public participation in politics is participation in elections. With the participation of the community participation of people naturally become the main capital in development, it is already evident from the history of the first elections held in 1955-2014. But participation much to the disappointment of the election results as getting here is getting low awareness of society to elect a leader, though the government is always looking for a way out for increased participation of the autonomous In developing countries such as Indonesia the low level of participation of the community will affect the development process , So also was the low participation of society in the making of public policy implementation in Indonesia. Adapaun various explanations put forward observers on their abstentions including the first administrative problems, both technical problems, a third lower linkage on politics and the fourth calculation nationwide that voters decided not to choose consciously decided not to vote, the election is deemed not had an impact on changes in himself, even because there is no preferred partner.

\section{REFERENCES}

[1] Eriyanto, Abstentions In the elections, the study of LSI Monthly Edition 05 September 2007, quoted www.lsi.co.id

[2] Political Act, 2003, Act No. 12 of 2003 on General Election, p .35

[3] Miriam Budiardjo, Fundamentals of Political Science, Jakarta: Gramedia 2008, hal.367

[4] Miriam Budiardjo, Fundamentals of Political Science, Jakarta: Gramedia, 2008, p.381

[5] Kacung Marijan, Indonesia Political System, Jakarta: Prenadamedia Group 2010, Hal.128

[6] Miriam Budiardjo, the fundamentals of political science, Jakarta: Gramedia 2008, Hal.367

[7] Wahyudi Kumorotomo, Ethics of Public Administration, Jakarta: Rajawali Press, 1999, p. 112 
[8] Sudijono Sastroadmojo, Political behavior, Semarang Teachers' Training College Press, 1995, Hal.74

[9] Michael Roskin, Political science: New Jersy, Prentice, 2003.

[10] Miriam Budiardjo, Fundamentals of Political Science, Jakarta: Gramedia, 2008.106 